\title{
A COMPARATIVE STUDY OF THE RADIOLYSIS OF USED TRANSFORMER OIL AND OIL CONTAINING 1, 2, 4-TRICHLORBENZENE UNDER THE INFLUENCE OF GAMMA-RADIATION
}

\author{
Z.I. Iskenderova \\ Institute of Radiation Problems of Azerbaijan National Academy of Science, \\ AZ 1143, Baku, Azerbaijan \\ E-mail: zenfira_iskenderova@mail.ru
}

\begin{abstract}
A comparative study of the radiolysis of used transformer oil and oil containing 1, 2, 4-trichlorbenzene (TCB) under the influence of gamma-radiation was carried out. Dependence of concentration of $\mathrm{H}_{2}, \mathrm{H}_{2} \mathrm{O}_{2}$, $\mathrm{pH}$-indicator and IR-spectra of $\gamma$-irradiated samples from absorbed doses in the range of $4 \ldots 136 \mathrm{kGy}$ was studied. The $\mathrm{pH}$-value dependence and concentration of hydrogen peroxide as a function of the absorbed dose is studied. Irradiation leads to increasing of acidity, related with dechlorination of TCB molecules. It is found that during the radiolysis of transformer oil containing TCB in the presence of dissolved oxygen, radiation-initiated oxidation of the oil takes place (formation of $\mathrm{H}_{2} \mathrm{O}_{2}, \mathrm{CO}_{2}$ ).
\end{abstract}

\section{INTRODUCTION}

Today, issues related to the determination of the performance of various units and assemblies of nuclear power plants under ionizing radiation in the case at various emergencies remain relevant. There are a number of works devoted to the study of the most functionally important components of electrical equipment, including transformer oils [1-3]. The issues became particularly relevant after the accident at Chernobyl NPP in 1986, after which a number of accidents with a level greater than INES 4 (International Nuclear Events Scale) were identified. Currently, the power sector uses the transformer oil "Sovtol-10" with $10 \%$ trichlorbenzene, although the production of $\mathrm{PCB}$ containing oils including "Sovtol-10" forbidden at the end of last century. At present the cross polluted oils widely used in transformers that contain admixtures of "Sovtol-10". This kind of oils after purification may contain trichlorbenzene with concentration about $50 \mathrm{ppm}$. The presence of chlorine aromatic compounds in oils effects on chemical transformations and change of electrical characteristics in oil [3]. Oil in transformers as usual is affected by high temperature and electrical field in the operation period. In this case chemical processes also going on by radicals and ions formed under high electrical field in transformer oil. In the case of emergency situations in nuclear reactors electrical equipment is effected by ionizing particles, mainly by $\gamma$ radiation, because they are located far from reactors.

There are only a few investigations related to radiation treatment of TCBs containing transformer oils. The high radiation resistance of 1,2,3, 4tetrachlorbenzene was observed in [4], where it was irradiated in insulating oil at $114 \mathrm{kGy}$ adsorbed dose. The $\gamma$-radiolysis of TCB in transformer oil was provided in [5] at $0,9 \mathrm{kGy} / \mathrm{h}$ dose rate and range of dose $13 \ldots 108 \mathrm{kGy}$. It was shown that the main products of $\gamma$ radiolysis of 1,2,4-trioclorbenzene in transformer oil are 1,3-dichlorbenzene, 1, 4-dichlorbenzene and monochlorbenzene. Decomposition degree of TCB
$(200 \mathrm{mg} / \mathrm{kg}$ ) is $65 \%$ at $108 \mathrm{kGy}$. Dose constant is equal to $8.5 \cdot 10^{-3} \mathrm{kGy}^{-1}$ [5].

Meanwhile, the study of the mechanism of radiolysis of such complex systems as mixtures of TCB in transformer oil is complicated by a multitude of chemical processes taking place both in transformer oil and TCB. Therefore, a comparative study of the radiolysis of $\mathrm{TCB}$, transformer oil, and a mixture of transformer oil with TCB, is of interest.

In this work $\gamma$-radiolysis of 3 systems: pure TCB, used transformer oil and mixtures of transformer oil with TCB was studied. A comparative study of the kinetics of the formation of gaseous products, such as $\mathrm{H}_{2}$ and $\mathrm{CO}_{2}$, the formation of hydrogen peroxide and the $\mathrm{pH}$ value change under $\gamma$-irradiation of the above mentioned systems is carried out.

\section{EXPERIMENTAL}

The TCB produced by EMD Millipore Corporation, Germany (Assay, area $\% \geq 98.0 \%$, density $\left(d=1.453\left(20^{\circ} \mathrm{C}\right) \ldots 1.456\left(40{ }^{\circ} \mathrm{C}\right) \mathrm{g} \cdot \mathrm{cm}^{-3}\right)$ was used. The samples were irradiated by $\gamma$-ray from isotope ${ }^{60} \mathrm{Co}$ at static conditions and dose rate measured by ferrosulphate dosimetry was $0.21 \mathrm{~Gy} / \mathrm{s}$ in glass ampoules with volume $15 \mathrm{ml}$ in the presence of adsorbed oxygen. The adsorbed dose was in the range $4 \ldots 140 \mathrm{kGy}$. pH-measurements were provided by Instruction Manual of Basic pHS-25 pH-meter. Analysis of liquid products was provided by gas chromatography Agilent Technology-7820 A. $\mathrm{H}_{2} \mathrm{O}_{2}$ analysis was carried out by chemical methods. IR-spectra were registered on Fourier-Spectrometer Varian-640 FT-IR in the range $4000 . .400 \mathrm{~cm}^{-1}$.

\section{RESULTS AND DISCUSSION \\ 1. RADIOLYSIS OF TRICHLORBENZENE}

Concentration dependence of $\mathrm{H}_{2} \mathrm{O}_{2}$ and $\mathrm{H}_{2}$ on adsorbed doses at the TCB radiolysis is given in Fig. 1 . 


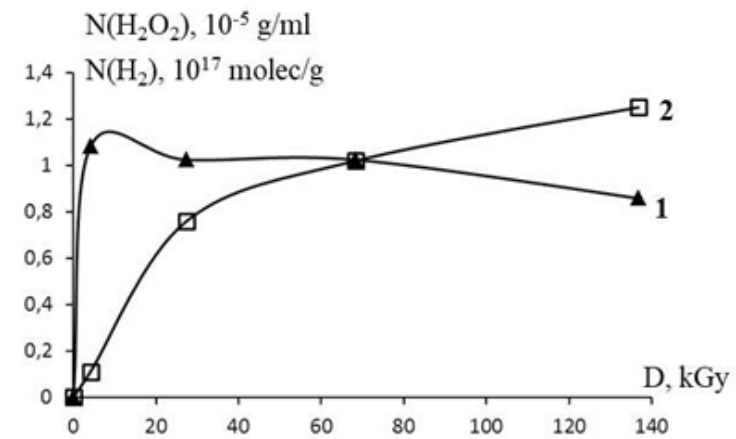

Fig. 1. Concentration dependence of $\mathrm{H}_{2} \mathrm{O}_{2}$ (1) and $\mathrm{H}_{2}(2)$ on adsorbed dose at the TCB radiolysis

$$
(I=0,21 G y / s)
$$

As seen, the concentration of $\mathrm{H}_{2} \mathrm{O}_{2}$ increases by raising doses up to $\sim 4 \mathrm{kGy}$, then decreases at high doses. Radiation chemical yield of $\mathrm{H}_{2} \mathrm{O}_{2}$ calculated from initial part of kinetic curves is equal to 0.76 molec./100 eV. Concentration of $\mathrm{H}_{2}$ is increased with dose raising and reaches stationary value at $>60 \mathrm{kGy}$. Initial radiation chemical yield of $\mathrm{H}_{2}$ is equal to 0.045 and close to radiation-chemical yield of $\mathrm{H}_{2}$ at the radiolysis of benzene [6].

Table 1 shows the dependence of $\mathrm{pH}$-indicators on adsorbed doses.

Table 1

Dependence of $\mathrm{pH}$-value on adsorbed dose at the radiolysis of TCB $(I=0.21 \mathrm{~Gy} / \mathrm{s})$

\begin{tabular}{|c|c|}
\hline Adsorbed dose, $\mathrm{kGy}$ & $\mathrm{pH}$ \\
\hline 0 & 6.4 \\
\hline 4.1 & 6.1 \\
\hline 27.4 & 4.4 \\
\hline 68.4 & 3.4 \\
\hline 136.8 & 3.1 \\
\hline
\end{tabular}

As seen the $\mathrm{pH}$-indicators are decreasing by dose raising and is equal to 3 at $136.8 \mathrm{kGy}$.

Chemical changes at TCB radiolysis is shown also by the IR-spectroscopy. In Fig. 2 the IR-spectra of irradiated TCB samples at various adsorbed doses in the range to $136.8 \mathrm{kGy}$ were presented.

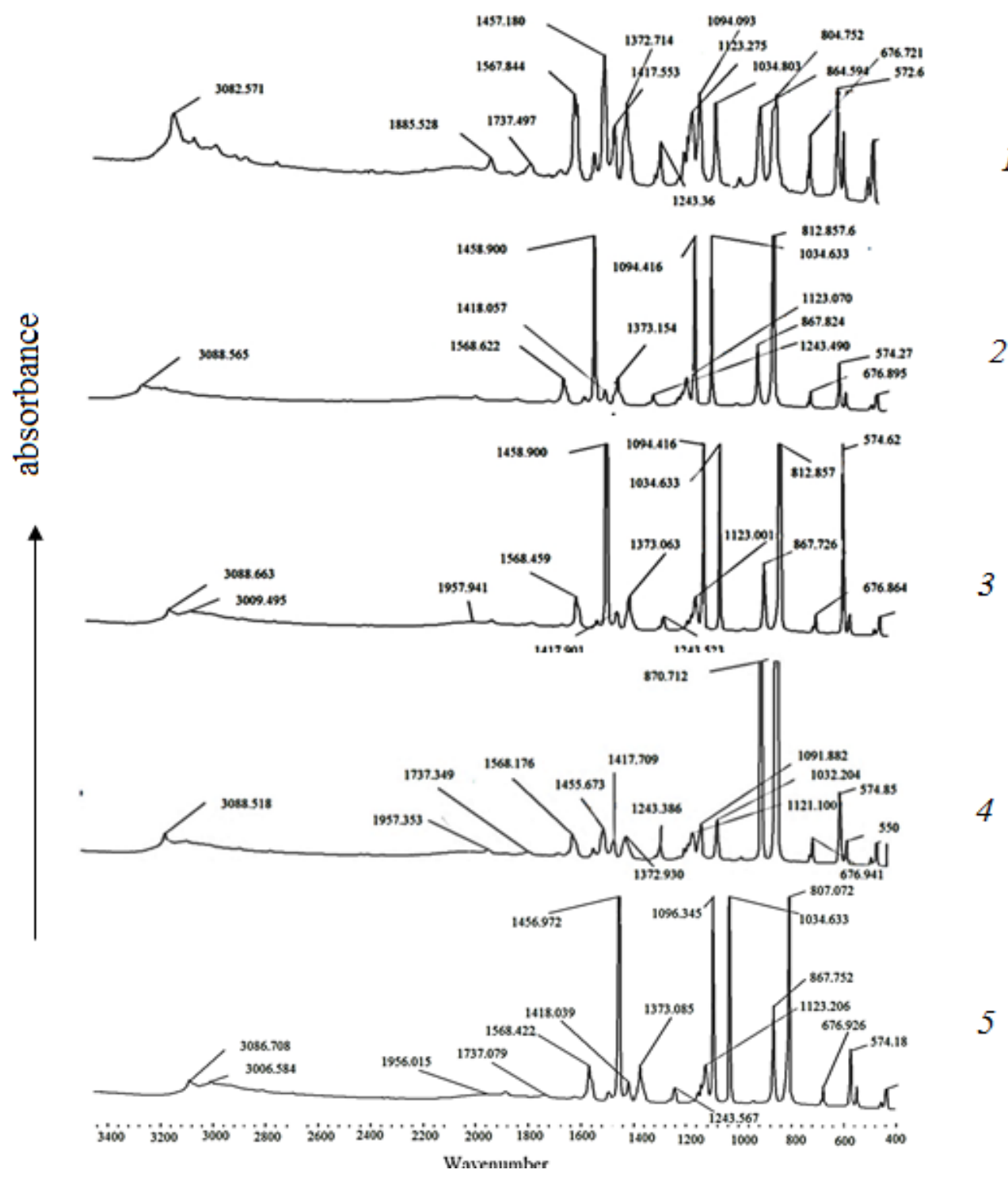

Fig. 2. IR-spectra of TCB samples at various adsorbed doses $(1-D=0 ; 2-D=4.1 ; 3-D=27.4 ; 4-D=68.4 ; 5-D=136.8 k G y)$ 
As seen in the IR-spectra the lot of absorption bonds were identified in the range of $1800 \ldots 500 \mathrm{~cm}^{-1}$. The intensity of $=\mathrm{C}-\mathrm{H}\left(\lambda \sim 3030 \mathrm{~cm}^{-1}\right)$ is decreased by increasing of radiation dose. In the range of $1600 \ldots 1500 \mathrm{~cm}^{-1}-\mathrm{C}=\mathrm{C}-$ increasing of radiation dose leads to redistribution of the intensity of the relevant bonds. In the range of $860 \ldots 690 \mathrm{~cm}^{-1}=\mathrm{C}-\mathrm{H}$ intensity of relevant bonds is slightly increasing. In the range of $900 \ldots .500 \mathrm{~cm}^{-1}=\mathrm{C}-\mathrm{Cl}$ intensity of bonds is decreased by increasing of dose, related with dechloraination of the TCB.

\section{INFLUENCE OF TRICHLORBENZENE ON THE RADIOLYSIS OF TRANSFORMER OIL}

Two series of experiments were carried out, in which concentration dependence of $\mathrm{CO}_{2}, \mathrm{H}_{2} \mathrm{O}_{2}$, and $\mathrm{pH}$ value in the used transformer oil, without TCB as a function of the absorbed dose, and the dose dependence of above parameters during radiolysis of used transformer oil, containing $5 \ldots 40 \mathrm{ppm}$ TCB was studied. Under normal conditions, transformer oil can dissolve a fairly large amount of air (10\% of the oil volume). The oxygen content in air dissolved in transformer oil is $30.2 \%[5,7]$.

It was found that the $\mathrm{pH}$ of the used oil decreases with increasing dose, which is due to the formation of acids during irradiation. Used oil also contains products of an acidic nature, but their formation significantly increases with increasing irradiation dose (Fig. 3).

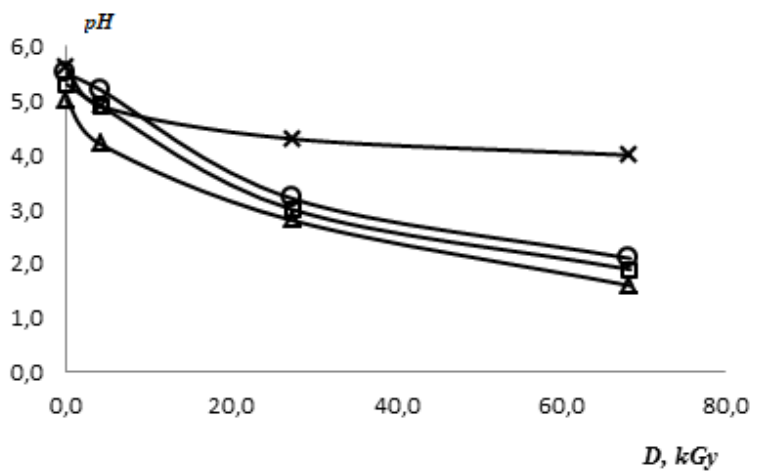

Fig. 3. Dependence of the acidity in transformer oil as of the absorbed dose at different initial TCB concentrations in the range of $5 . .40 \mathrm{ppm}$ :

○- 5 ppm TCB; $\square-15$ ppm TCB; $\triangle-40$ ppm TCB; $x$ - Transformer oil

As can be seen from the figure, the $\mathrm{pH}$ value decreases with increasing absorbed dose: at a TCB concentration of $5 \mathrm{ppm}$, the $\mathrm{pH}$ decreases from 5.5 to $2.1(62 \%)$, at TCB $40 \mathrm{ppm}$ from 5.0 to $1.6(68 \%)$.

In the Fig. 4 concentration dependence of $\mathrm{CO}_{2}$ from the absorbed dose at different initial concentrations of TCB in transformer oil is shown.

As seen the maximum of $\mathrm{CO}_{2}$ concentration at $27.4 \mathrm{kGy}$ is observed in the kinetic curve, and the radiation-chemical yield is 0.18 molec. $/ 100 \mathrm{eV}$.

Fig. 5 shows concentration dependence of $\mathrm{H}_{2} \mathrm{O}_{2}$ as a function of the absorbed dose at different initial concentrations of TCB in transformer oil.

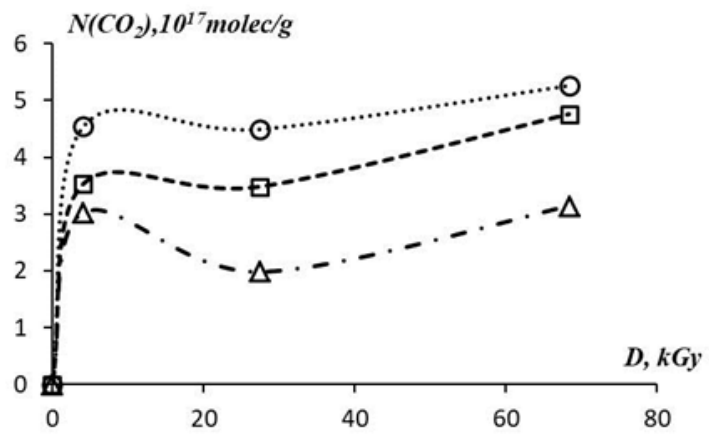

Fig. 4. Concentration dependence of $\mathrm{CO}_{2}$ as a function of the adsorbed dose at different initial concentration of TCB in transformer oil: $\bigcirc-5$ ppm TCB; $\square-15$ ppm TCB; $\triangle-40$ ppm TCB

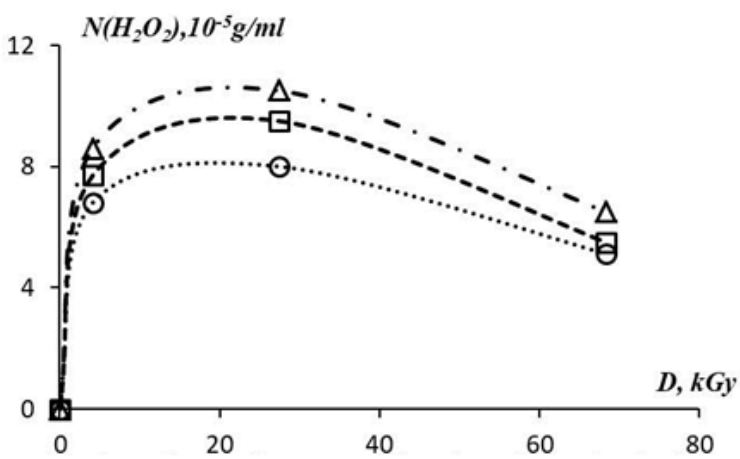

Fig. 5. Concentration dependence of $\mathrm{H}_{2} \mathrm{O}_{2}$ as a function of the absorbed dose at different initial concentration of TCB in transformer oil:

○- 5 ppm TCB; $\square-15$ ppm TCB; $\triangle-40$ ppm TCB

The formation of hydrogen peroxide, depending on the dose, which has a maximum at $\sim 27 \mathrm{kGy}$ is observed. With a further dose increase, the concentration of $\mathrm{H}_{2} \mathrm{O}_{2}$ decreases, which indicates the course of secondary reactions with its participation.

It can be seen that as the dose increases, the concentration of both products increases and reaches a steady-state concentration. The steady-state concentration is achieved at a dose of $4.1 \ldots 10$ and $4.1 \ldots 27 \mathrm{kGy}$ in the case of the formation of $\mathrm{CO}_{2}$ and $\mathrm{H}_{2} \mathrm{O}_{2}$, respectively. Further growth of the absorbed dose leads to a decrease in the concentration of both products.

From the initial parts of the kinetic curves, the radiation-chemical yields of formation of $\mathrm{CO}_{2}$ and $\mathrm{H}_{2} \mathrm{O}_{2}$ are determined, which are given in Table 2.

Table 2

Radiation-chemical yields of $\mathrm{H}_{2} \mathrm{O}_{2}, \mathrm{CO}_{2}$, and $\mathrm{pH}$ values at different initial concentrations of TCB in transformer oil

\begin{tabular}{|c|c|c|}
\hline \multirow{2}{*}{$C_{\mathrm{TCB}}, \mathrm{ppm}$} & \multicolumn{2}{|c|}{$G$, molec./100 eV } \\
\cline { 2 - 3 } & $\mathrm{H}_{2} \mathrm{O}_{2}$ & $\mathrm{CO}_{2}$ \\
\hline 0 & 3.6 & 0.177 \\
\hline 5 & 4.7 & 1.18 \\
\hline 15 & 5.4 & 1.39 \\
\hline
\end{tabular}


As can be seen from the table, the radiationchemical yield of both products increases with increasing of TCB concentration. The data obtained indicate an increase in oxidation process and the formation of acid products during the radiolysis of transformer oil in the presence of TCB in the irradiated oil. Along with oxidation processes, the molecules of transformer oil components undergo decomposition under the action of ionizing radiation, which leads to the formation of gaseous products - hydrogen and hydrocarbons. Hydrogen and hydrocarbon products as $\mathrm{CH}_{4}, \mathrm{C}_{2} \mathrm{H}_{4}, \mathrm{C}_{2} \mathrm{H}_{6}, \mathrm{C}_{3} \mathrm{H}_{8}, \mathrm{C}_{4} \mathrm{H}_{10}, \mathrm{C}_{5} \mathrm{H}_{12}$, and $\mathrm{C}_{6} \mathrm{H}_{14}$ have been identified (Table 3 ).

Table 3

Radiation-chemical yields of gaseous products at different initial concentrations of TCB in transformer oil

\begin{tabular}{|c|c|c|c|c|}
\hline \multirow{2}{*}{$C_{\mathrm{TCB}}, \mathrm{ppm}$} & \multicolumn{4}{|c|}{$G$, molec./100 eV } \\
\cline { 2 - 5 } & $\mathrm{H}_{2}$ & $\mathrm{CH}_{4}$ & $\mathrm{C}_{2} \mathrm{H}_{4}$ & $\mathrm{C}_{2} \mathrm{H}_{6}$ \\
\hline 0 & 0.375 & $6.5 \cdot 10^{-4}$ & $3 \cdot 10^{-4}$ & $1.3 \cdot 10^{-4}$ \\
\hline 5 & 0.432 & $20 \cdot 10^{-4}$ & $6.3 \cdot 10^{-4}$ & $5.9 \cdot 10^{-4}$ \\
\hline 15 & 0.424 & $13 \cdot 10^{-4}$ & $5.5 \cdot 10^{-4}$ & $4.5 \cdot 10^{-4}$ \\
\hline 40 & 0.390 & $8 \cdot 10^{-4}$ & $4.7 \cdot 10^{-4}$ & $3 \cdot 10^{-4}$ \\
\hline
\end{tabular}

As can it be seen from the Table molecular hydrogen is formed with the higher radiation-chemical yield, which slightly increases with the growthof TCB in transformer oil. The radiation-chemical yield of the remaining identified gaseous products is less than $10^{-4}$ molec./100 eV, although the tendency of growth of the radiation-chemical yield with increasing TCB concentration in oil also occurs for these products.

Radiolytic decomposition of TCB in transformer oil mainly occurs in reactions with solvated electrons due to high electron affinity of the molecules of TCB, which is typically for chlororganic compounds [8] (Table 4). Below given the rate constants of solvated electrons with molecules of chlorine-containing aromatic compounds and oxygen, as the air dissolved in oil the oxygen concentration is $\sim 30 \%$.

Table 4

The rate constants of the $e_{\text {solv }}$. with molecules of chlororganic compounds [8-11]

\begin{tabular}{|l|c|}
\hline $\begin{array}{c}\text { Chlororganic compounds, } \\
\text { benzene and oxygen }\end{array}$ & $\begin{array}{c}\text { Rateconstant, } \\
\mathrm{M}^{-1} \cdot \mathrm{s}^{-1}\end{array}$ \\
\hline Monochlorobenzene & $5 \cdot 10^{8}$ \\
\hline $\begin{array}{l}\text { Chlorbiphenils (KC 300, } \\
\text { KC 400) }\end{array}$ & $10^{9} \ldots 10^{10}$ \\
\hline Dichlorobiphenyl & $3.8 \cdot 10^{9}$ \\
\hline Tetrachlorobiphenyl & $3 \cdot 10^{9}$ \\
\hline Decahlorobiphenyl & $7 \cdot 10^{9}$ \\
\hline 4-chlorophenol & $1 \cdot 10^{9}$ \\
\hline $\mathrm{O}_{2}$ & $2 \cdot 10^{10}$ \\
\hline Benzene & $2 \cdot 10^{7}$ \\
\hline
\end{tabular}

At a concentration of TCB in oil equal to $40 \mathrm{ppm}$, the ratio of the rates of the electron capture by the molecules of TCB and oxygen under the experimental conditions is:

$$
\frac{\omega_{1}}{\omega_{2}}=\frac{k_{1}[T C B]}{k_{2}\left[O_{2}\right]}=\frac{5 \cdot 10^{8} \cdot 2.2 \cdot 10^{-4}}{2 \cdot 10^{10} \cdot 2.97 \cdot 10^{-4}}=1.8 \cdot 10^{-2} .
$$

Calculation shows that in the irradiated oil, electrons are mainly captured by oxygen and the expected yield of the TCB molecules decomposition is approximately $10^{-2}$ of the radiation-chemical yield of the $e_{\text {solv }}$.
In the case of 1, 2, 4-trichlorbenzene radiolysis, the following reactions take place.

$$
\begin{gathered}
\mathrm{C}_{6} \mathrm{H}_{3} \mathrm{Cl}_{3} \rightarrow \mathrm{C}_{6} \mathrm{H}_{3} \mathrm{Cl}_{2}+\mathrm{Cl}\left(\text { or } \mathrm{C}_{6} \mathrm{H}_{2} \mathrm{Cl}_{2}+\mathrm{H}\right), \\
\quad \mathrm{e}+\mathrm{C}_{6} \mathrm{H}_{3} \mathrm{Cl}_{3} \rightarrow \mathrm{C}_{6} \mathrm{H}_{3} \mathrm{Cl}_{2}+\mathrm{Cl}^{-}, \\
\mathrm{C}_{6} \mathrm{H}_{3} \mathrm{Cl}_{3} \rightarrow \mathrm{C}_{6} \mathrm{H}_{3} \mathrm{Cl}_{3}^{+}+\mathrm{e} .
\end{gathered}
$$

The formed $\mathrm{Cl}$ and $\mathrm{H}$ atoms will react with TCB molecules:

$$
\begin{aligned}
& \mathrm{H}+\mathrm{C}_{6} \mathrm{H}_{3} \mathrm{Cl}_{3} \rightarrow \mathrm{HCl}+\mathrm{C}_{6} \mathrm{H}_{3} \mathrm{Cl}_{2}, \\
& \mathrm{Cl}+\mathrm{C}_{6} \mathrm{H}_{3} \mathrm{Cl}_{3} \rightarrow \mathrm{HCl}+\mathrm{C}_{6} \mathrm{H}_{2} \mathrm{Cl}_{3}, \\
& \mathrm{Cl}^{-}+\mathrm{C}_{6} \mathrm{H}_{3} \mathrm{Cl}_{3} \rightarrow \mathrm{C}_{6} \mathrm{H}_{3} \mathrm{Cl}_{2}+\mathrm{Cl}_{2}^{-} .
\end{aligned}
$$

Part of electrons react with solved oxygen molecules, but in case of pure $\mathrm{C}_{6} \mathrm{H}_{3} \mathrm{Cl}_{3}$ radiolysis the rate of this reaction is low due to effective capture of electrons with TCB molecules and its high concentration in irradiated samples.

\section{CONCLUSION}

A chemical transformation in the transformer oil, containing TCB admixtures under $\gamma$-irradiation by the methods of chemical analysis, chromatography and IRspectroscopy were studied. The changes of $\mathrm{pH}$ indicators, $\mathrm{CO}_{2}, \mathrm{H}_{2} \mathrm{O}_{2}$, hydrocarbons and intensity of IR-spectra in dependence from absorbed dose at various initial concentrations of TCB in transformer oil were determined.

It was established, that the presence of TCB in oil leads to increasing of acidity, rate of oxidation processes, yields of hydrocarbon gases and intensity of IR-spectra. Probably it is related with reactions of $\mathrm{O}_{2}^{-}$ formed by capture of $e_{\text {solv }}$ and reactions of free radicals and atoms with molecules of transformer oil components (alkanes and aromatic compounds).

\section{REFERENCES}

1. А.П. Тютнев, С.Г. Боев, Д.Н. Садовничий, Е.А. Голуб. Влияние мощности дозы ионизирующего излучения на работоспособность маслонаполненного электрооборудования для АЭС // Bопросы атомной науки и техники. Серия «Физика радиационного воздействия на 
радиоэлектронную аппаратуру». М., 1992, в. 2-3, c. $16-22$.

2. С.Д. Лизунов, Л.Г. Куцин, А.П. Тютнев, Л.К. Случанко, Т.И. Морозова. Исследование радиационной стойкости электроизоляционных материалов, применяемых в высоковольтном оборудовании на Чернобыльской АЭС // Bonросы атомной науки и техники. Серия «Физика радиаџионного воздействия на радиоэлектронную annapamypy». М., 1992, в. 2-3, с. 100-103.

3. З.И. Искендерова, М.А. Курбанов. Исследование радиационной стойкости трансформаторного масла в поле ионизирующего излучения // Международный научно-исследовательский журнал «Евразийский союз ученых» (ЕСУ). 2018, т. 11, в. 56, с. 57-59.

4. I. Webber. The radiolytic degradation of polychlorinated biphenyls in electrical insulating oils // Canadian Electrical Association (CEA), Montreal, Quebec, 1983, p. 70-77.

5. N. Tajima, J. Hasegawa, K. Horioka. An Approach to Reuse of PCB-Contaminated Transformer Oil Using Gamma Radiolysis // Journal of Nuclear Science and Technology. 2008, v. 45, p. 601-609.
6. А.К. Пикаев. Современная радиационная химия. Радиолиз газов и жидкостей. М.: «Наука», 1986, $440 \mathrm{c.}$

7. Solubility of gases in transformer oi.leg.co.ua/transformatoriHeoriya/rastvorimost qazovv-transformatornom-masle.html
8. M. Chaychian,
C. Johnes,
D. Poster,

J. Silvermann, P. Neta, R. Huie, M. Al-Sheikhly. Radiolytic dechlorination of polychlorinated biphenyls in transformer oil and in marine sediment // Radiation Physics and Chemistry. 2002, v. 65, p. 473-478.

9. N. Getoff, S. Solar. Radiation induced decomposition of chlorinated phenols in water // Radiation Physics and Chemistry. 1988, v. 31, p. 121130.

10. A. Trifan, I. Calinescu, D. Martin. Transformation of polychlorinaded biphenyls (psbs) into nonhazardous products by electron beam treatment // Rev. Chim. 2009, v. 60, p. 1053-1055.

11. T. Sawai, T. Shimokawa, Y. Shinozaki. The radiolytic-chain dechlorination of polychlorinated biphenils in alkaline 2-propanol solutions // Bulletin of Chemical Society of Japan. 1974, v. 47, p. 1889-1893.

\section{СРАВНИТЕЛЬНОЕ ИЗУЧЕНИЕ РАДИОЛИЗА ТРАНСФОРМАТОРНОГО МАСЛА И МАСЛА, СОДЕРЖАЩЕГО 1, 2, 4-ТРИХЛОРБЕНЗОЛ, ПОД ДЕЙСТВИЕМ ГАММА-ИЗЛУЧЕНИЯ}

\section{3.И. Искендерова}

Проведено сравнительное исследование радиолиза отработанного трансформаторного масла и масла, содержащего 1, 2, 4-трихлорбензол, под воздействием гамма-излучения. Изучена зависимость концентрации $\mathrm{H}_{2}, \mathrm{H}_{2} \mathrm{O}_{2}$, $\mathrm{pH}$-индикатора и ИК-спектров $\gamma$-облученных образцов от доз в диапазоне $4 \ldots 136$ кГр. Облучение приводит к повышению кислотности, связанной с дехлорированием молекул трихлорбензола (ТХБ). Изучена зависимость рН-показателя и концентрации перекиси водорода от поглощенной дозы. Установлено, что при радиолизе трансформаторного масла, содержащего ТХБ в присутствии растворенного кислорода, происходит радиационное окисление масла (образование $\mathrm{H}_{2} \mathrm{O}_{2}, \mathrm{CO}_{2}$ ).

\section{ПОРІВНЯЛЬНЕ ВИВЧЕННЯ РАДІОЛІЗУ ТРАНСФОРМАТОРНОГО МАСТИЛА І МАСТИЛА, ЩО МІСТИТЬ 1, 2, 4-ТРИХЛОРБЕНЗОЛ, ПІД ДІЄЮ ГАММА-ВИПРОМІНЮВАННЯ}

\section{I. Іскендерова}

Проведено порівняльне дослідження радіолізу відпрацьованого трансформаторного мастила і мастила, що містить 1, 2, 4-трихлорбензол, під дією гамма-випромінювання. Вивчено залежність концентрації Н ${ }_{2}$, $\mathrm{H}_{2} \mathrm{O}_{2}$, pH-індикатора і ІК-спектрів $\gamma$-опромінених зразків від доз у діапазоні $4 \ldots 136$ кГр. Опромінення призводить до підвищення кислотності, пов'язаної з дехлоруванням молекул трихлорбензолу (ТХБ). Вивчено залежність рН-показника і концентрації перекису водню від поглиненої дози. Встановлено, що при радіолізі трансформаторного мастила, що містить ТХБ у присутності розчиненого кисню, відбувається радіаційне окислення мастила (утворення $\mathrm{H}_{2} \mathrm{O}_{2}, \mathrm{CO}_{2}$ ). 